\title{
Perspective Evaluation of a Poultry-Breeding Enterprise Financial Resources Based on Seasonal Decomposition
}

\author{
Kadochnikova E.I'., Sungatullina L.B. ${ }^{2}$, Agzamova R. R. ${ }^{3}$, Abduazizova G. Sh. ${ }^{4}$ \\ ${ }^{1}$ PhD in Economics, Associate Professor, Institute of Management, Economics and Finance, \\ Dept. economics theory and econometrics, ${ }^{1}$ Kazan Federal University, Russia. \\ ${ }^{2}$ PhD in Economics, Associate Professor, Institute of Management, Economics and Finance, \\ ${ }^{1}$ Kazan Federal University, Russia. \\ ${ }^{3}$ Institute of Management, Economics and Finance, Bachelor's Center in Economics, \\ ${ }^{1}$ Kazan Federal University, Russia. \\ ${ }^{4}$ Bachelor, Institute of Management, Economics and Finance, Bachelor's Center in Economics, \\ ${ }^{1}$ Kazan Federal University, Russia.
}

\begin{abstract}
The authors used prospective estimates of revenue and accounts receivable, obtained on the basis of an additive trend-seasonal model, to forecast the poultry enterprise financial resources. The study highlights the fact that the classical decomposition of the trend-seasonal model into trend, seasonal and random components is possible and convenient for forecasting the financial resources of a poultry enterprise that has a seasonality in production. The forecast estimates presented in the article confirmed the main hypothesis of the study - if there are objective seasonal fluctuations for a poultry enterprise, there is a tendency to increase sales revenue and accounts receivable due to limited customer liquidity. The results of the obtained empirical estimates confirmed the practical use feasibility of an additive trend-seasonal model based on the classical decomposition for predicting the financial resources of a poultry enterprise.
\end{abstract}

Keywords: sales revenue, accounts receivable, forecast, seasonal decomposition, trend-seasonal model

\section{INTRODUCTION}

It is necessary to conduct a financial resources full forecast analysis of activities for poultry enterprise stable operation. The seasonal trend of poultry production is determined by the birds' physiology. Modern technologies for keeping birds allow smoothing out seasonal fluctuations in production to some extent. However, the high susceptibility of birds to various seasonal factors does not allow to achieve completely rhythmic production. Accounting for seasonal fluctuations is of great practical importance for overcoming or mitigating them and is especially necessary when forecasting and planning the main indicators of the enterprise. A prognostic analysis of revenue and receivables makes it possible to identify trends in the financial resources of an enterprise, indicate to management the paths for further successful development, point out errors in economic activity, and also identify reserves for the financial results growth, which ultimately allows more successful activities $[1 ; 2 ; 3 ; 4]$. Analysis of of a poultry enterprise allows one providing timely management with information forming an objective opinion on the activities for the reporting period compared to the previous year, as well as identifying factors that caused changes in the indicators of financial resources and develop measures to optimize their receipt and use $[5 ; 6 ; 7 ; 8]$. The financial resources growth strengthens the company's position in the production and financial sphere, as well as stimulates the investment inflow $[9 ; 10 ; 11]$. There is an analysis of the long - and medium-term outlook, but a detailed and accurate forecast is not possible in the long term [12]. Due to this, short-term forecasts are often used, since their results are more accurate and reliable $[13 ; 14]$. Predictive analysis serves as the basis for making decisions on the development and improvement of the organization's functioning. Therefore, the purpose of this study is to forecast revenue from sales and receivables as sources of the enterprise financial resources. The main hypothesis of the study is that if there are objective seasonal fluctuations for a poultry enterprise, there is a tendency for sales revenue to grow and accounts receivable to grow.

\section{METHODS}

We used the quarterly data on revenue and accounts receivable of poultry enterprises from 2016 to 2020 for the purpose of forecasting. The trend and the decomposition method that the forecast will be based on should be chosen depending on the tasks set for the forecaster, as well as considering all the advantages and disadvantages of known methods. This study uses an additive trend-seasonal model based on the classical decomposition:

$\mathrm{Yt}=\mathrm{Tt}+\mathrm{St}+\mathrm{Et}$,

where $\mathrm{Tt}$ - time trend, regular component that characterizes the overall development trend;

St - seasonal component, which is characterized by the seasonal fluctuations period duration, their amplitude;

Et - a random component that represents small deviations that cannot be predicted in the long term. 
International Journal of Engineering Research and Technology. ISSN 0974-3154, Volume 13, Number 11 (2020), pp. 3568-3574

(C) International Research Publication House. https://dx.doi.org/10.37624/IJERT/13.11.2020.3568-3574

Building a model is reduced to calculating the values of $\mathrm{T}, \mathrm{S}$, and $\mathrm{E}$ for each level of the series. The method of building an additive model includes the following steps:

1. alignment of the source series using the moving average method;

2. assessment of the seasonal component;

3. analytical alignment of sequence level of $(\mathrm{T}+\mathrm{E})$;

4. calculating $\mathrm{T}$ values using the obtained trend equation;
5. calculating the series levels using an additive model, multiplying the $\mathrm{T}$ levels by the values of the seasonal component for the corresponding quarters;

6. calculating the error in the additive model.

\section{RESULTS AND DISCUSSION}

The time series graph of the company's revenue indicates seasonal fluctuations. During the year, revenue increases in the 3rd quarter. This is due to the specifics of the organization, since the largest revenue is generated during the summerautumn period.

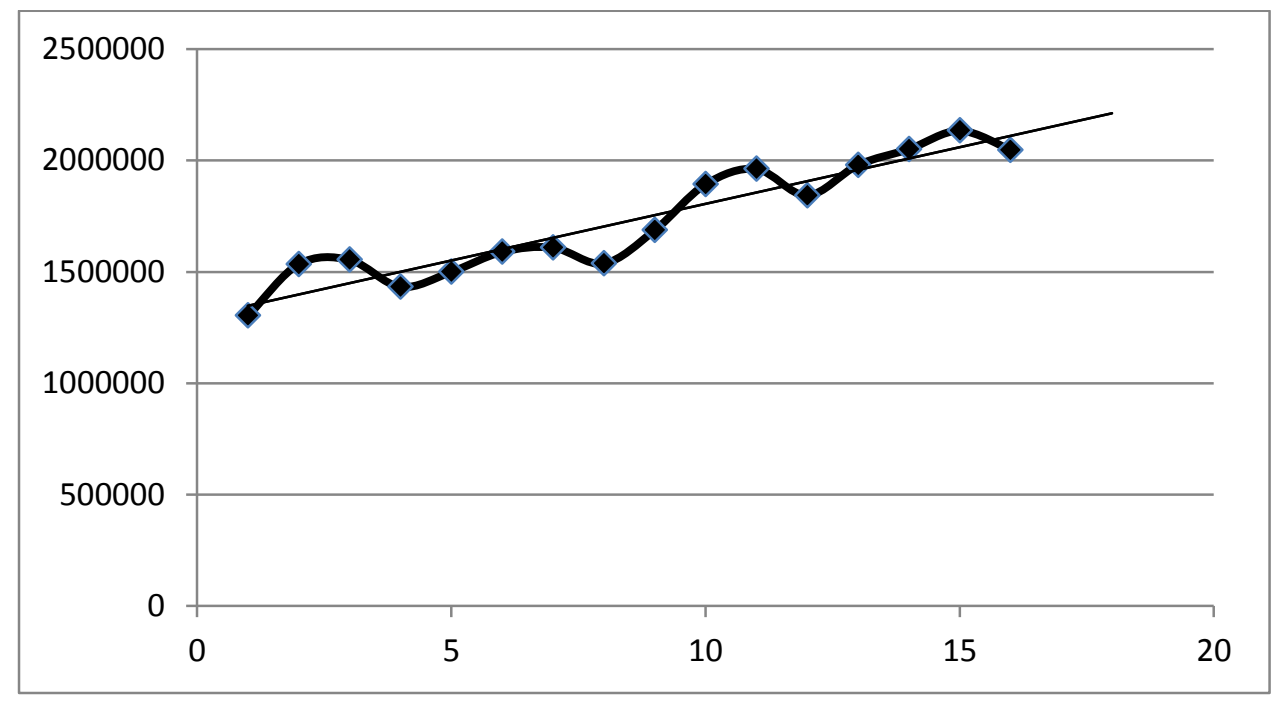

Fig. 1. Dynamics of the company's revenue for 2016-2019

The calculation of the seasonal component estimates at the first stage of decomposition is presented in Table 1 .

Table 1. Calculation of the seasonal components estimates in the revenue of the enterprise

\begin{tabular}{|c|c|c|c|}
\hline Period & Revenue & $\begin{array}{c}\text { 3-quarter moving } \\
\text { average }\end{array}$ & $\begin{array}{c}\text { Seasonal component } \\
\text { estimate }\end{array}$ \\
\hline Q1 2016 & 1304573 & - & - \\
\hline Q2 2016 & 1535235 & 1464780 & 70454,67 \\
\hline Q3 2016 & 1554533 & 1507742 & 46791,33 \\
\hline Q4 2016 & 1433457 & 1496189 & $-62732,3$ \\
\hline Q1 2017 & 1500578 & 1508199 & $-7621,33$ \\
\hline Q2 2017 & 1590563 & 1567012 & 23550,67 \\
\hline Q3 2017 & 1609896 & 1579611 & 30284,67 \\
\hline Q4 2017 & 1538375 & 1611898 & -73523 \\
\hline Q1 2018 & 1687423 & 1706495 & -19072 \\
\hline Q2 2018 & 1893687 & 1847895 & 45791,67 \\
\hline Q3 2018 & 1962576 & 1900013 & 62563 \\
\hline Q4 2018 & 1843776 & 1928957 & $-85181,3$ \\
\hline Q1 2019 & 1980520 & 1958585 & 21935,33 \\
\hline Q2 2019 & 2051458 & 2055519 & -4061 \\
\hline Q3 2019 & 2134579 & 2077860 & 56719,33 \\
\hline Q4 2019 & 2047542 & - & - \\
\hline
\end{tabular}


International Journal of Engineering Research and Technology. ISSN 0974-3154, Volume 13, Number 11 (2020), pp. 3568-3574

(C) International Research Publication House. https://dx.doi.org/10.37624/IJERT/13.11.2020.3568-3574

At the next stage, we will adjust the estimate of the seasonal component. To do this, we find the total amount of estimates for the $n$-th quarter. The average estimate of the seasonal component is the arithmetic mean of the total sum of the estimates. We calculate the sum of the average estimates of the seasonal component and compare with the zero value.
Seasonal effects should be mutually repaid, and when using the additive model, the sum of the average estimates of the seasonal component should be zero. Multiplying each value of the seasonal component estimate by the obtained coefficient, we get adjusted estimates of the seasonal component.

Table 2. Calculation of the seasonal component average estimates

\begin{tabular}{|c|c|c|c|c|c|}
\hline \multirow{2}{*}{ Year } & \multicolumn{4}{|c|}{ Quarter } & \multirow[t]{2}{*}{ Sum } \\
\hline & 1 & 2 & 3 & 4 & \\
\hline 2016 & - & 70454,67 & 46791,33 & $-62732,3$ & \\
\hline 2017 & $-7621,33$ & 23550,67 & 30284,67 & -73523 & \\
\hline 2018 & -19072 & 45791,67 & 62563 & $-85181,3$ & \\
\hline 2019 & 21935,33 & -4061 & 56719,33 & & \\
\hline Total for the n-th quarter & -4758 & 135736 & 196358,3 & -221437 & \\
\hline $\begin{array}{l}\text { Average seasonal component estimate } \\
\text { for the nth quarter, } \mathrm{Sn} \text { avg }\end{array}$ & -1586 & 33934 & 49089,58 & $-73812,2$ & 7625,361 \\
\hline $\begin{array}{l}\text { Adjusted seasonal component estimate, } \\
\qquad \mathrm{Sn}\end{array}$ & $-3492,34$ & 32027,66 & 47183,24 & $-75718,6$ & 0 \\
\hline
\end{tabular}

To identify the trend component at the next stage of decomposition, we use the linear trend formula $[15,16]$ :

$\mathrm{Y}_{\mathrm{t}}=\mathrm{a}_{0}+\mathrm{a}_{1} * \mathrm{t}$,

where $Y_{t}$ - revenue-line-aligned revenue;

$\mathrm{a}_{0}$ - free member; $\mathrm{a}_{1}-$ trend equation coefficient;

$\mathrm{t}$ - quarter.

To calculate the coefficients of the trend component, we use the usual least-squares method [17; 18] and MS Excel. We determine the predicted revenue values $\left(\mathrm{T}_{\mathrm{t}}+\mathrm{S}_{\mathrm{t}}\right)$, model errors and present them graphically.

Table 3. Calculation of revenue after decomposition

\begin{tabular}{|c|c|c|c|c|c|c|}
\hline Period & $\mathrm{Yt}$ & $\mathrm{St}$ & $\mathrm{Tt}+\mathrm{Et}=\mathrm{Yt}-\mathrm{St}$ & $\mathrm{Tt}$ & $\mathrm{Tt}+\mathrm{St}$ & $\mathrm{Yt}-(\mathrm{Tt}+\mathrm{S})$ \\
\hline 1 & 1304573 & $-3492,34$ & 1308065 & 1338915 & 1335423 & -30850 \\
\hline 2 & 1535235 & 32027,66 & 1503207 & 1390966 & 1422994 & 112241 \\
\hline 3 & 1554533 & 47183,24 & 1507350 & 1443017 & 1490201 & 64332,34 \\
\hline 4 & 1433457 & $-75718,6$ & 1509176 & 1495068 & 1419350 & 14107,1 \\
\hline 5 & 1500578 & $-3492,34$ & 1504070 & 1547120 & 1543627 & $-43049,2$ \\
\hline 6 & 1590563 & 32027,66 & 1558535 & 1599171 & 1631198 & $-40635,2$ \\
\hline 7 & 1609896 & 47183,24 & 1562713 & 1651222 & 1698405 & $-88508,9$ \\
\hline 8 & 1538375 & $-75718,6$ & 1614094 & 1703273 & 1627554 & $-89179,1$ \\
\hline 9 & 1687423 & $-3492,34$ & 1690915 & 1755324 & 1751831 & $-64408,4$ \\
\hline 10 & 1893687 & 32027,66 & 1861659 & 1807375 & 1839402 & 54284,58 \\
\hline 11 & 1962576 & 47183,24 & 1915393 & 1859426 & 1906609 & 55966,95 \\
\hline 12 & 1843776 & $-75718,6$ & 1919495 & 1911477 & 1835758 & 8017,703 \\
\hline 13 & 1980520 & $-3492,34$ & 1984012 & 1963528 & 1960036 & 20484,43 \\
\hline 14 & 2051458 & 32027,66 & 2019430 & 2015579 & 2047607 & 3851,383 \\
\hline 15 & 2134579 & 47183,24 & 2087396 & 2067630 & 2114813 & 19765,75 \\
\hline 16 & 2047542 & $-75718,6$ & 2123261 & 2119681 & 2043962 & 3579,507 \\
\hline
\end{tabular}


International Journal of Engineering Research and Technology. ISSN 0974-3154, Volume 13, Number 11 (2020), pp. 3568-3574

(C) International Research Publication House. https://dx.doi.org/10.37624/IJERT/13.11.2020.3568-3574

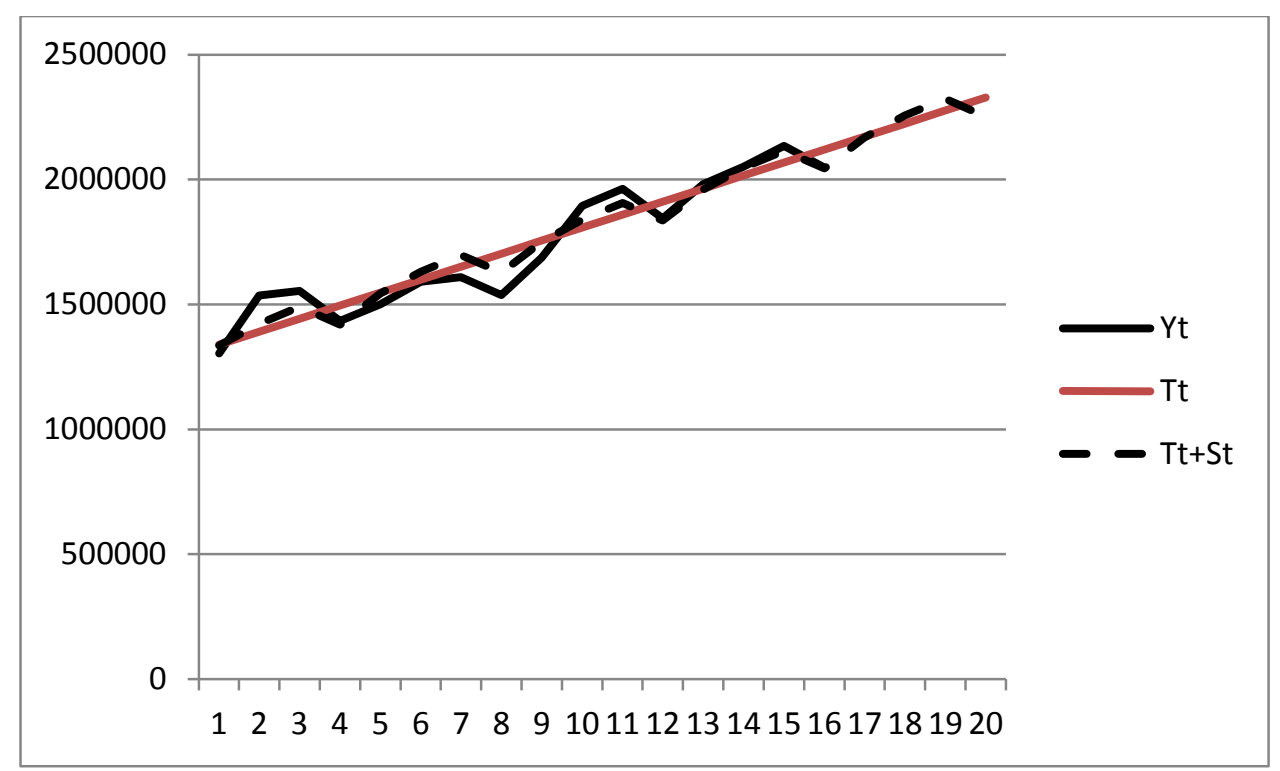

Fig. 2. Actual and post-forecast values of the company's revenue

Using the seasonal component and trend values for 2020, we find the forecast data for the next 4 quarters (Table 4). Predicted values do not contain a random Et component.

Table 4. Revenue forecast of the company for 2019-2021

\begin{tabular}{|c|c|c|c|}
\hline Period & St & Tt & Tt + St \\
\hline Q1 2020 & $-3492,34$ & 2171732 & 2168240 \\
\hline Q2 2020 & 32027,66 & 2223783 & 2323017 \\
\hline Q3 2020 & 47183,24 & 2275834 & 2252167 \\
\hline Q4 2020 & $-75718,6$ & 2327885 & \\
\hline
\end{tabular}

Table 4 shows that the smallest revenue is expected in the first quarter of 2020, and the largest revenue is expected in the third quarter of 2020 .

Time series graph of accounts receivable (Fig.3) indicates seasonal fluctuations.

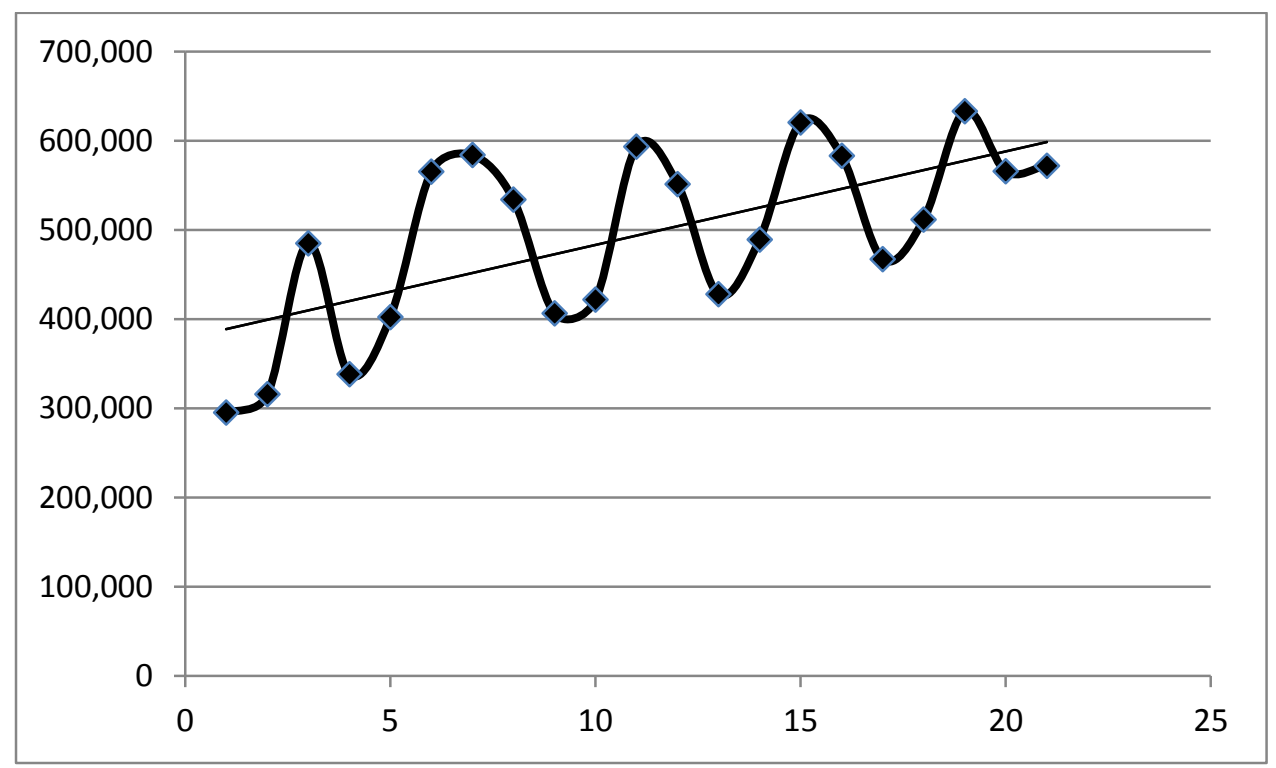

Fig. 3. Dynamics of the company's accounts receivable for 2015-2019 
International Journal of Engineering Research and Technology. ISSN 0974-3154, Volume 13, Number 11 (2020), pp. 3568-3574 (C) International Research Publication House. https://dx.doi.org/10.37624/IJERT/13.11.2020.3568-3574

The forecast analysis of accounts receivable is presented in Tables 5,6 and in Figure 4.

Table 5. Calculation of the company's accounts receivable after decomposition

\begin{tabular}{|c|c|c|c|c|c|c|}
\hline Period & $\mathrm{Yt}$ & St & $\begin{array}{c}\mathrm{Tt}+\mathrm{Et}= \\
\mathrm{Yt}-\mathrm{St}\end{array}$ & $\mathrm{Tt}$ & $\mathrm{Tt}+\mathrm{St}$ & $\mathrm{Yt}-(\mathrm{Tt}+\mathrm{St})$ \\
\hline 1 & 255123 & $-45693,23$ & 300816,23 & 354892,32 & 309199,09 & $-54076,09$ \\
\hline 2 & 275640 & $-18089,97$ & 293729,97 & 369374,74 & 351284,77 & $-75644,77$ \\
\hline 3 & 445141 & 67487,77 & 377653,23 & 383857,16 & 451344,92 & $-6203,92$ \\
\hline 4 & 298259 & $-3704,57$ & 301963,57 & 398339,58 & 394635,01 & $-96376,01$ \\
\hline 5 & 414875 & $-45693,23$ & 460568,23 & 412822,00 & 367128,76 & 47746,24 \\
\hline 6 & 577855 & $-18089,97$ & 595944,97 & 427304,41 & 409214,45 & 168640,55 \\
\hline 7 & 596259 & 67487,77 & 528771,23 & 441786,83 & 509274,60 & 86984,40 \\
\hline 8 & 546471 & $-3704,57$ & 550175,57 & 456269,25 & 452564,69 & 93906,31 \\
\hline 9 & 360716 & $-45693,23$ & 406409,23 & 470751,67 & 425058,44 & $-64342,44$ \\
\hline 10 & 365939 & $-18089,97$ & 384028,97 & 485234,09 & 467144,12 & $-101205,12$ \\
\hline 11 & 567606 & 67487,77 & 500118,23 & 499716,51 & 567204,28 & 401,72 \\
\hline 12 & 495718 & $-3704,57$ & 499422,57 & 514198,93 & 510494,36 & $-14776,36$ \\
\hline 13 & 470835 & $-45693,23$ & 516528,23 & 528681,35 & 482988,11 & $-12153,11$ \\
\hline 14 & 572229 & $-18089,97$ & 590318,97 & 543163,77 & 525073,80 & 47155,20 \\
\hline 15 & 683476 & 67487,77 & 615988,23 & 557646,19 & 625133,95 & 58342,05 \\
\hline 16 & 646179 & $-3704,57$ & 649883,57 & 572128,60 & 568424,04 & 77754,96 \\
\hline 17 & 492218 & $-45693,23$ & 537911,23 & 586611,02 & 540917,79 & $-48699,79$ \\
\hline 18 & 536374 & $-18089,97$ & 554463,97 & 601093,44 & 583003,48 & $-46629,48$ \\
\hline 19 & 657946 & 67487,77 & 590458,23 & 615575,86 & 683063,63 & $-25117,63$ \\
\hline 20 & 590647 & $-3704,57$ & 594351,57 & 630058,28 & 626353,71 & $-35706,71$ \\
\hline
\end{tabular}

Table 6. Forecast of the company's accounts receivable in 2020

\begin{tabular}{|c|c|c|c|}
\hline Period & St & $\mathrm{Tt}$ & St*Tt \\
\hline Q1 2020 & $-45693,23$ & 644540,70 & 598847,47 \\
\hline Q2 2020 & $-18089,97$ & 659023,12 & 640933,15 \\
\hline Q3 2020 & 67487,77 & 673505,54 & 740993,30 \\
\hline Q4 2020 & $-3704,57$ & 687987,96 & 684283,39 \\
\hline
\end{tabular}




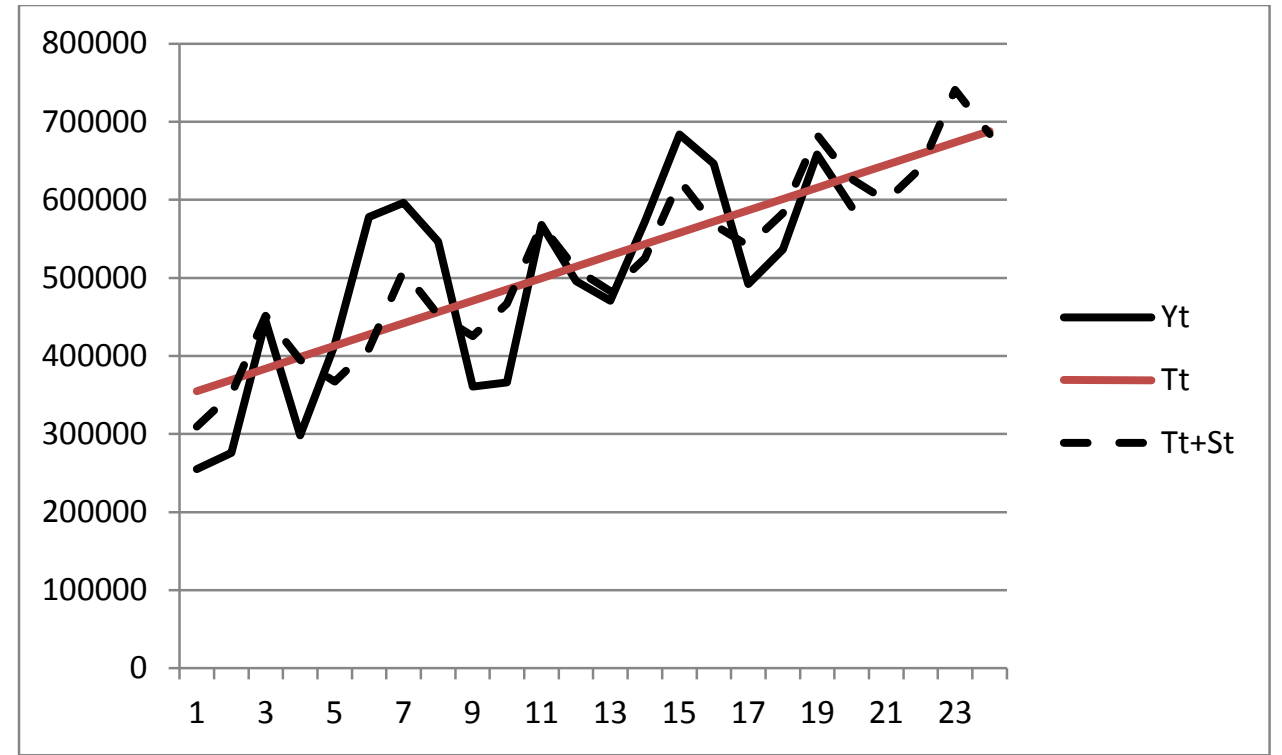

Fig. 4. Actual and post-forecast values of the company's accounts receivable

According to the forecast values made using the additive time series model, the smallest amount of accounts receivable is expected in the first quarter of $2020-598,847$. 47 thousand rub, the largest amount of debt - in the $3 \mathrm{rd}$ quarter of 2020 (740 993.30 thousand. rub).

\section{SUMMARY}

Based on the financial resources forecast of the poultry enterprise, the following conclusions can be drawn:

- there is a steady growth trend in revenue from sales and receivables, while the amplitude of fluctuations in the values of forecasted indicators reaches a maximum value in each $3^{\text {rd }}$ quarter of the analyzed period. This is due to the seasonality of poultry production.

It is necessary to note that the poultry industry depends on the level of egg production, service life and safety of laying hens, the level of broilers' productive capabilitie usage, meat marketability, preservation of young animals, feed consumption - all this leads to additional costs that reduce the profit of the organization. Therefore, the company should pay attention to reducing the level of unproductive costs, reducing the production costs, as well as increasing the quality of fertilizers, seeds and feed.

\section{CONCLUSIONS}

The forecast estimates of the company's revenue from sales received in the study confirm the hypothesis of profit from sales steady growth. This will be possible due to uniform output, efficient use of fixed assets, and elimination of working time losses. In conditions of inflation, deferred payment leads to the fact that the company actually receives only a part of the cost of products sold, so to reduce the company's accounts receivable, it is necessary to regularly and promptly implement a number of the following measures:

- analyze the composition and structure of accounts receivable for specific customers, as well as the terms of debt formation and the terms of their possible repayment;

- analyze the ratio of receivables and payables;

- monitor the turnover of receivables and payables, the status of settlements on overdue debts.

\section{ACKNOWLEDGEMENTS}

The work is performed according to the Russian Government Program of Competitive Growth of Kazan Federal University.

\section{REFERENCES}

[1] Kulikova LI, Garyncev AG, Goshunova AV. Doubtful debts allowance develoment: Stages and methods of calculation. Mediterranean Journal of Social Sciences. 2015 Feb 28;6(1 S3):448.

[2] Sokolov AY, Elsukova TV. Using ABC to enhance throughput accounting: an integrated management approach. Academy of Strategic Management Journal. 2016 Jan 7;15:8-15.

[3] Bieliková T, Bányiová T, Piterková A. Prediction techniques of agriculture enterprises failure. Procedia Economics and Finance. 2014 Jan 1;12:48-56.

[4] Sungatullina LB, Neizvestnaya DV, Kadochnikova EI. The Efficiency Analysis of Measures to Improve the Labor Productivity. The Journal of Social Sciences Research. 2018;4:260-6. 
[5] Dias CS, Rodrigues RG, Ferreira JJ. What's new in the research on agricultural entrepreneurship?. Journal of rural studies. 2019 Jan 1;65:99-115.

[6] Ding Y, Wang L, Li Y, Li D. Model predictive control and its application in agriculture: A review. Computers and Electronics in Agriculture. 2018 Aug 1;151:104-17.

[7] Fenyves V, Tarnóczi T, Zsidó K. Financial Performance Evaluation of agricultural enterprises with DEA Method. Procedia Economics and Finance. 2015 Jan 1;32(15):423-31.

[8] Fitz-Koch S, Nordqvist M, Carter S, Hunter E. Entrepreneurship in the agricultural sector: A literature review and future research opportunities. Entrepreneurship Theory and Practice. 2018 Jan;42(1):129-66.

[9] Gellynck X, Cárdenas J, Pieniak Z, Verbeke W. Association between innovative entrepreneurial orientation, absorptive capacity, and farm business performance. Agribusiness. 2015 Jan;31(1):91-106.

[10] Giannakis E, Bruggeman A. The highly variable economic performance of European agriculture. Land Use Policy. 2015 May 1;45:26-35.

[11] Grande J, Madsen EL, Borch OJ. The relationship between resources, entrepreneurial orientation and performance in farm-based ventures. Entrepreneurship and Regional Development. 2011 Apr 1;23(3-4):89-111.
[12] Kadochnikova EI, Zapparova ZN, Sungatullina LB. The analysis of resource productivity factors: the models on panel data. Journal of Advanced Research in Dynamical and Control Systems. 2018;10(10 Special Issue):1735-40.

[13] Uzun V, Shagaida N, Lerman Z. Russian agriculture: Growth and institutional challenges. Land Use Policy. 2019 Apr 1;83:475-87.

[14] Nesterov VN, Kozlova NN. Methodology for the technical and economic analysis of a product at the projection stage. InIssues and Trends in Interdisciplinary Behavior and Social Science 2018 May 20 (pp. 117-124). CRC Press.

[15] Stock JH, Watson MW. Introduction to Econometrics. 3rd Edition, Harvard University, Princeton University. 2011.

[16] Lyzhova AV, Kadochnikova EI, Karimova GZ. Forecasting Financial Performance of Agricultural Enterprises Based on Supply Chain Operation in Seasonal Decomposition. Int. J Sup. Chain. Mgt Vol. 2019 Oct;8(5):241-248.

[17] Greene WH. Econometric Analysis. 8th Edition, Stern School of Business, New York University. 2018.

[18] Wooldridge JM. Introductory Econometrics. A modern approach. 5th edition, Michigan State University, South-Western, 2013. 